\title{
The Interaction Between the European Court of Justice and National Courts in Preliminary Ruling Proceedings: Some Institutional and Procedural Observations
}

\section{Allan Rosas"}

\section{Introduction}

In view of the considerable diversity of international courts and other dispute settlement bodies, ${ }^{1}$ generalizations should be made with great care. Each judicial system has its own institutional and procedural setting and the substantive applicable rules often present their own specificities. This, of course, is not to deny that there may be common threads which call for at least partly similar solutions, such as the question of the independence and impartiality of judges and the rules of evidence. ${ }^{2}$

This article will deal with the judicial system of the European Union (EU) and more specifically, the two-layered system consisting of the joint involvement of the national courts of the EU Member States and the European Court of Justice $(E C J)^{3}$ in a mechanism known as the preliminary ruling procedure. The aim is to elucidate the interaction between national courts and the ECJ in dealing with preliminary rulings and to highlight some institutional and procedural challenges stemming from the parallel existence of two players, the national court and the ECJ, which are based on sets of rules of different origin. The national legal orders not only pre-

* Judge at the European Court of Justice.

1 R. Mackenzie et al., The Manual on International Courts and Tribunals, $2^{\text {nd }}$ ed. (2010).

2 For a search for commonalities, convergence and cross-fertilization, see C. Brown, A Common Law of International Adjudication (2007).

3 According to Article 19(1) of the Treaty on European Union (TEU), the Court of Justice of the European Union consists of the Court of Justice, the General Court (previously the Court of First Instance) and specialized tribunals. As the focus of this article is on the preliminary ruling procedure, and as the possibility to transfer, under Article 256(3) of the Treaty on the Functioning of the European Union (TFEU), preliminary ruling cases to the General Court "in specific areas laid down by the Statute" has not been used so far, the present article will deal with the Court of Justice only. 
date the EU legal order but they also present significant differences among themselves. The EU legal order is of more recent origin and its status in relation to the national legal orders is less settled.

On the other hand, the EU legal order, with regard to its substantive, institutional and procedural specificities, differs in many significant respects from public international law regimes; its interaction with national law is much more intense than with public international law. ${ }^{4}$ In the same vein, the interaction, in the context of the preliminary ruling procedure in particular, between the national courts of the Member States and the ECJ differs significantly from the jurisdictional relations which exist between national courts and international courts operating under public international law. ${ }^{5}$ It is accordingly necessary to consider the specificities of the EU legal order and its judicial system in particular, before embarking on a more concrete discussion of some of the institutional and procedural challenges which mark the preliminary ruling procedure.

It will not be possible in this context to carry out a comparative study of procedures corresponding to the EU preliminary ruling procedure existing in other judicial systems. It suffices to note here that the preliminary ruling procedure of the Court of Justice of the Andean Community (Tribunal de Justicia de la Communidad Andina), where this procedure is frequently used with respect to intellectual property rights in particular, in many respects resembles the corresponding EU procedure. ${ }^{6}$ The same goes, in principle, for the East African Court of Justice, although the use of the preliminary ruling procedure has so far been very limited indeed. ${ }^{7}$

4 A. Rosas \& L. Armati, EU Constitutional Law: An Introduction, $2^{\text {nd }}$ rev. ed. (2012), passim.

5 On the relations between national courts and international courts in general, see Y. Shani, Regulating Jurisdictional Relations Between National and International Courts (2007).

6 L. J. Diez-Canseco Núñez, 'The Andean Tribunal of Justice: Reality and Perspectives' (2015), PowerPoint presentation for a conference organized by the EFTA Court, available at http:/www.eftacourt.int/fileadmin/user_upload/Files/Events/An dean_Court_Presentation__Read-Only__Compatibility_Mode_.pdf (last visited 22 September 2018), mentions that as of June 2015, the Court had dealt with 3047 preliminary rulings. See more generally Mackenzie, supra note 1, 296.

7 J. Eudes Ruhangisa, 'The East African Court of Justice: Ten Years of Operation (Achievements and Challenges)', Paper for presentation at workshop on the role of the EACJ in EAC integration, Kampala 1-2 November 2011, available at http://eacj. org/wp-content/uploads/2013/09/EACJ-Ten-Years-of-Operation.pdf (last visited 22 September 2018), 22-23. For a preliminary ruling given, see Reference for a Preliminary Ruling under Article 34 of the Treaty by the High Court of the Republic of 
As to the EFTA Court, called upon to apply and interpret the Agreement on a European Economic Area (EEA), requests for advisory opinions are more frequent. As the notion of advisory opinion suggests, this Court's opinions are not legally binding in the strict sense. ${ }^{8}$ The EEA judicial system nevertheless resembles in many respects the EU system and, whilst the former will not be given specific consideration in this article, many of the observations to be presented in the following will be relevant also for the EEA. As to the newly created possibility for the European Court of Human Rights to give advisory opinions as requested by the highest courts and tribunals of Contracting Parties under Protocol No. 16 to the Convention for the Protection of Human Rights and Fundamental Freedoms (European Convention on Human Rights), this Protocol is not yet in force and will not be considered here. ${ }^{9}$

\section{The EU Judicial System}

The legal order of the EU, while it differs in many respects from that of federal states, has evolved into a veritable constitutional order which is not to be equated with public international law regimes. ${ }^{10}$ Without explaining this state of affairs in any greater detail, it should be recalled that the EU legal order is endowed with a fairly developed internal hierarchy of norms, including, at so-called primary law level, a Charter of Fundamental Rights, that the Union possesses legislative powers, with legislative acts adopted as

Uganda in the Proceedings between the Attorney General of the Republic of Uganda and Tom Kyahurwenda of 31 July 2015.

8 The practical importance of this difference as compared to the preliminary ruling procedure before the ECJ seems to be limited, however. See generally C. Baudenbacher et al. (eds.), The EEA and the EFTA Court: Decentred Integration (2014), notably 83-185.

9 CETS No. 214. According to its Article 8(1), the Protocol will enter into force on the first day of the month following the expiration of a period of three months after the date on which ten Contracting Parties to the Convention have expressed their consent to be bound. See also J. Gerards, Advisory Opinions, Preliminary rulings and the New Protocol No. 16 to the European Convention of Human Rights: A Comparative and Critical Appraisal, 21 Maastricht Journal of European and Comparative Law (2014), 630.

10 A. von Bogdandy \& J. Bast (eds.), Principles of European Constitutional Law, $2^{\text {nd }}$ rev. ed. (2010); Rosas \& Armati, supra note 4; R. Schütze, European Constitutional Law (2012); T. Isiksel, Europe's Functional Constitution: A Theory of Constitutionalism Beyond the State (2016). 
a rule by the European Parliament and the Council jointly, the latter acting by qualified majority, and that there is a comprehensive system of remedies and administrative, quasi-judicial and judicial control. Union law enjoys primacy over the laws of Member States and may, under certain conditions, not only be directly applicable but also have direct effect in their legal orders, in other words may be directly invoked by individuals before courts and authorities. ${ }^{11}$

At the same time, the EU may be seen as an example of "multilevel governance", where both Union institutions and bodies and Member States' national authorities take part in the application and implementation of Union law. Union law is to a large extent applied and implemented at national level; in some cases, Union law not only assigns tasks to particular organs of Member States such as their national parliaments ${ }^{12}$ but also requires the designation of special national administrative bodies for the execution of Union law and may regulate some aspects of their status and functions such as their independence from the national government. ${ }^{13}$ Not only is Union law to be applied at the national level but national law, whilst it cannot as a rule, be directly applied by Union bodies, including the Union Courts, is in many respects to be taken into account at Union level and, exceptionally, can even be applied by a Union institution. ${ }^{14}$ In this context, reference can also be made to the so-called infringement procedure, whereby the European Commission, by virtue of Article 258 TFEU, may initiate actions against Member States for failure to comply with Union law. In such cases, the ECJ may be called upon to assess the

11 Rosas \& Armati, supra note 4, 66-85.

12 On the role of national parliaments in the EU constitutional structure, see Articles 12 and 48 TEU and Articles 70, 85 and 88 TFEU; Rosas \& Armati, supra note 4, 106-108.

13 Rosas \& Armati, supra note 4, 109-110.

14 See e.g. Council Regulation (EC) No 207/2009 of 26 February 2009 on the Union mark (codified version), [2009] O.J. L 78/1, which, for instance, in Article 8(4), contains references to national law in a way which may make it applicable at Union level, see e.g. Edwin v. EUIPO, Case 263/09, Judgment of 5 July 2011, [2011] EU:C:2011:452; EUIPO v. Szajner, Case 598/14 P, Opinion of AG Kokott of 1 December 2016 [2016] ECLI:EU:C:2016:915. In a recent legislative act relating to the so-called Banking Union, the European Central Bank has been granted powers to apply also national legislation transposing Union directives or national legislation exercising options granted by Union regulations, see Article 4(3) of Council Regulation (EU) No. 1024/2013 of 15 October 2013 conferring specific tasks on the European Central Bank concerning policies relating to the prudential supervision of credit institutions, [2013] O.J. L 287/63. 
content of national law, in order to determine whether there is an infringement or not. ${ }^{15}$

This intertwinement of Union and national bodies, and Union and national law, may be seen in the EU judicial system as well. While the Union judiciary in the strict sense is composed of the two judicial bodies currently making up the Court of Justice of the European Union (which includes the ECJ and the General Court $)^{16}$ and of a certain number of quasi-judicial appeal boards of some Union administrative agencies, ${ }^{17}$ the national courts of the Member States, too, form part of the EU judicial system. ${ }^{18}$ Even if they do not belong to the Court of Justice of the European Union as a Union institution, ${ }^{19}$ they can be conceived as EU courts as they are called upon to apply not only national law but also Union law, sometimes on quite a regular basis. Moreover, when the matter concerns an act or an omission of a national authority, the case has to be brought before the national courts. This is so even when the circumstances give rise to Union law. Only if the national judge so decides, will the case be brought before the ECJ as a request for a preliminary ruling.

In Opinion 1/09 relating to a draft agreement on a European and Community patents judicial system, ${ }^{20}$ the ECJ, citing Article 19(1) of the Treaty on European Union (TEU), emphasized that both the Court of Justice and

15 But the Commission and the Court should, with regard to legislative, regulatory and administrative acts, take into account the interpretation given to them in national case law. See T. Materne, La procedure en manquement d'État. Guide à la lumière de la jurisprudence de la Cour de justice de l'Union européenne (2012), 195, 207.

16 Until 31 August 2016, there was also a Civil Service Tribunal functioning as a specialized court as envisaged in Article 19(1) TEU, see, Regulation (EU, Euratom) 2016/1192 of the European Parliament and of the Council of 6 July 2016 on the transfer to the General Court of jurisdiction at first instance in disputes between the European Union and its servants, [2016] O.J. L 200/137.

17 See e.g. M. Navin-Jones, A Legal Review of EU Boards of Appeal in Particular the European Chemicals Agency Board of Appeal, 21 European Public Law (2015), 143; P. Chirulli \& L. De Lucia, Specialised Adjudication in EU Administrative Law: The Boards of Appeal of EU Agencies, 40 European Law Review (2015), 832.

18 A. Rosas, The National Judge as EU Judge: Opinion 1/09, in P. Cardonnel et al. (eds.), Constitutionalising the EU Judicial System: Essays in Honour of Pernilla Lindh (2012), 105 [Rosas 2012]; A. Rosas, The National Judge as EU Judge: Some Constitutional Observations, 67 SMU Law Review (2014), 717.

19 Article 13 TEU lists as the Union's institutions the European Parliament, the European Council, the Council, the European Commission, the Court of Justice of the European Union, the European Central Bank and the Court of Auditors.

20 Opinion 1/09 EU:C:2011:123. See also Rosas 2012, supra note 18. 
the courts and tribunals of the Member States are the guardians of the EU legal order and that they "fulfil a duty entrusted to them both" of ensuring that in the interpretation and application of the Treaties, the law is observed. The national courts are "closely involved in the correct application and uniform interpretation of European Union law and also in the protection of individual rights conferred by that legal order". ${ }^{21}$

In fact, Article 19(1) TEU, while referring first to the ECJ, also instructs the Member States to provide "remedies sufficient to ensure effective legal protection in the fields covered by Union law". In the same vein, Article 47 of the EU Charter of Fundamental Rights, which is also applicable at the national level in a situation falling under Union law, ${ }^{22}$ provides for the right to an effective remedy and to a fair trial. There is an increasing tendency in ECJ case law to underline the importance of the principle of effective judicial protection recognized in Article 47 and the need to apply it also at national level, to fill in possible gaps or correct deficiencies in national law. As a result the authorities and courts of a Member State may be obliged to set aside a national provision deemed to be in conflict with Article 47 or some other provision of Union law, or at least to interpret it in the light of Article 47 or any other relevant provision, including, as the case may be, a provision of secondary EU law. ${ }^{23}$

The above discussion has concerned, in principle, all national courts, regardless of their place in the judicial hierarchy (leaving aside the fact that, as will be explained below, there is a difference between national courts of last instance and other national courts as far as their obligation to seek preliminary rulings from the ECJ is concerned). It should be added that Union law may, exceptionally, require the designation of national courts explicitly endowed with certain Union law functions. The most wellknown examples are the EU trade mark courts which according to Union trademark legislation must be designated by each Member State to deal

21 Opinion 1/09, supra note 20, paras. 69, 84-85.

22 See Article 51(1) of the EU Charter of Fundamental Rights and infra, at notes 41-43.

23 For recent examples, see SC Star Storage and Lesoochranárske zoskupenie, Joined Cases 439/14 and 488/14, 15 September 2016, [2016] EU:C:2016:688, paras. 45-46; VLK, Case 243/15, Judgment of 8 November 2016, [2016] EU:C:2016:838, paras. 64, 72-73. There seems to be a tendency to cite Article 47 of the Charter of Fundamental Rights (and, as the case may be, Article 19(1) TEU) rather than what has been called the "judicial autonomy of the Member States" with its principle of effectiveness. The word autonomy is misleading, as the two provisions mentioned impose an obligation (to provide remedies) rather to grant any autonomy in the true sense of the word, Rosas \& Armati, supra note 4, 272-273. 
with, inter alia, infringement actions. In the case of most infringement actions, a court lawfully seized in one Member State has jurisdiction extending to all Member States. ${ }^{24}$ The following discussion will not address the specificities of such specially designated national courts but will deal with national courts in general and their interaction with the ECJ in preliminary ruling proceedings.

\section{The Preliminary Ruling Procedure}

According to Article 267 of the Treaty on the Functioning of the European Union (hereinafter TFEU), where a question concerning the interpretation of the basic Treaties such as the TEU and the TFEU, or the validity and interpretation of legislative or other acts of the institutions, bodies, offices or agencies of the Union, is raised before "any court or tribunal of a Member State", that court or tribunal "may, if it considers that a decision on the question is necessary to enable it to give judgment", request the ECJ to give a ruling thereon. Whilst such a request is, in principle, an option ("may"), that option becomes an obligation, subject to certain qualifications, ${ }^{25}$ if the national court is an instance of last resort ("a court or tribunal of a Member State against whose decisions there is no judicial remedy under national law"). A lower court, too, must make a reference if it has serious doubts about the validity of a Union act, since national courts, according

24 Articles 95, 96 and 98 of Council Regulation (EC) No 207/2009 on the Community trade mark, [2009] O.J. L 78/1 (this Regulation has been amended by Regulation (EU) 2015/2424 of the European Parliament and of the Council of 16 December 2015, [2015] O.J. L 341/21, but, apart from the substitution of "Union" for "Community", these amendments do not affect what is said in the main text above). See also e.g. Combit Software, Case 223/15, Judgment of 22 September 2016, [2016] EU:C:2016:719.

25 In CILFIT and Others, Case 283/81, Judgment of 6 October 1982, [1982] EU:C:1982:335, the ECJ observed that even a national court of last resort need not make a referral to the ECJ 1) where the question to be referred is identical to a question on which the ECJ has already ruled, 2) where the reply to such a question may be clearly deduced from existing case law or 3) where the answer to the question admits of no reasonable doubt. This wording is not a verbatim citation of the judgment in CILFIT but borrows from Article 99 of the Rules of Procedure of the ECJ, [2012] O.J. L 265/1, which authorizes the Court to reply by reasoned order instead of a judgment in one of the three circumstances mentioned. 
to ECJ case law, are barred from declaring Union legal acts invalid. ${ }^{26} \mathrm{~A}$ Member State may not limit the right of national courts and tribunals to refer cases to the ECJ, the national courts deriving their competence (and as the case may be, their obligation) to request preliminary rulings directly from Article 267 TFEU. ${ }^{27}$

Although the national court may still order protective measures, particularly in connection with a reference relating to the validity of Union acts, the lodging of a request for a preliminary ruling nevertheless calls for the national procedure to be stayed until the ECJ has given its ruling. ${ }^{28}$ According to well-established case law, the ECJ is, in principle, obliged to answer the questions raised by the national judge (although there are some grounds for declaring a request inadmissible or concluding that the ECJ is not competent to give a ruling, see below). The ruling is binding on the national court, which, in giving full effect to the interpretation of Union law provided by the ECJ, ${ }^{29}$ decides on the final outcome of the case before it.

The number of requests for preliminary rulings has been steadily on the rise. While in 1965 the ECJ received only seven requests, the corresponding figures are 69 for 1975, 139 for 1985, 251 for 1993, 221 for 2003 and 436 for 2015. ${ }^{30}$ This development reflects not only the enlargement of the European Communities (since 1992, the EU) from the six pre-1973 Member States to the 28 Member States of today and the broadening of the reach of Union law, but also a greater inclination of national judges to turn to the ECJ for advice. There are certainly variations between the Member

26 Foto-Frost, Case 314/85, Judgment of 22 October 1987, [1987] EU:C:1987:452. See also the Recommendations to national courts and tribunals in relation to the initiation of preliminary ruling proceedings issued by the ECJ, [2016] O.J. C 439/1, paras. 7, 22. The previous Recommendations were issued in 2012, [2012] O.J. C 338/1.

27 See e.g. Cartesio, Case 210/06, Judgment of 16 December 2008, [2008] EU:C:2008:723; Melki and Abdeli, Cases 188/10 and 189/10, Judgment of 22 June 2010, [2010] EU:C:2010:363, para. 42; Puligencia Facility Esco, Case 689/13, Judgment of 5 April 2016, [2016] EU:C:2016:199, para. 32. In the last-mentioned case, the Court even seems to have applied the prohibition to limit by national law the competence to make preliminary ruling references to the relations between different compositions of the same national court.

28 See also Recommendations to national courts and tribunals, supra note 26, para. 23.

29 Ognyanov, Case 614/14, Judgment of 5 July 2016, [2016] EU:C:2016:514, paras. $28,34$.

30 Court of Justice of the European Union, Annual Report 2015 (2016), 93-94. In 2016, the Court has received 470 new requests for preliminary rulings. 
States as to the number of references made by their courts but these variations seem to be based at least partly on structural factors such as population size and national litigation proneness. ${ }^{31}$

The greater acceptance among national judges of the preliminary ruling mechanism is also reflected in the ever-increasing number of national constitutional courts which have started to use the mechanism..$^{32}$ In this way, national judges have increasingly come to endorse also the general tenets and principles of Union law, including the principles of primacy and direct effect. That said, some constitutional or supreme courts have reserved the right to verify whether a ECJ decision is in conformity with the national act transferring competence and powers to the Union, and at least in two cases, one involving the Czech Constitutional Court and the other, in a recent judgment, the Danish Supreme Court, the national court has refused to follow the ruling of the ECJ..$^{33}$

\section{When Does the ECJ Have Jurisdiction to Give a Ruling?}

The basic provision setting out the scope of the competence of the ECJ to give preliminary rulings is, of course, Article 267 TFEU: apart from questions concerning the validity of secondary law, the Court shall have jurisdiction to give rulings concerning the interpretation of the Treaties and of secondary law. The provision thus does not refer to the application of the law and the Court has held that when interpreting the Treaty, it "limits it-

31 M. Broberg \& N. Fenger, Variations in Member States' Preliminary References to the Court of Justice: Are Structural Factors (Part of) the Explanation?, 19 European Law Journal (2013), 488.

32 The constitutional courts which have referred cases to the ECJ are the constitutional courts of Austria, Belgium, France, Germany, Italy, Lithuania, Luxembourg, Poland, Slovenia and Spain. One of the most recent referrals, the first request submitted by the German Constitutional Court, relates to the legality of an announcement by the European Central Bank that it was ready, if need be, to buy an unlimited number of government bonds on the secondary market as well as the Bank's decision providing technical guidance in case action would become necessary. On this referral, see Gauweiler and Others, Case 62/14, Judgment of 16 June 2015, [2015] EU:C:2015:400; I. Pernice, A Difficult Partnership between Courts: The First Preliminary Reference by the German Federal Constitutional Court to the CJEU, 21 Maastricht Journal of European and Comparative Law 3 (2014), 3.

33 Judgment of the Czech Constitutional Court of 31 January 2012, File No Pl US 5/12; Judgment of the Danish Supreme Court of 6 December 2016, Case 15/2014. See more generally Rosas \& Armati, supra note 4, 70-71. 
self to deducing the meaning of the [Union] rules from the wording and spirit of the Treaty, it being left to the national court to apply in the particular case the rules which are thus interpreted". 34 That said, the distinction between application and interpretation is not always easy to uphold and an Advocate General of the Court has even suggested that "when a provision is applied its interpretation and application are interwoven and merge". 35

The question of the admissibility of requests for preliminary rulings and the scope of the competence of the ECJ to answer the questions raised has given rise to an extensive case law and literature which cannot be analyzed fully here. ${ }^{36}$ Important issues include the concept of court or tribunal appearing in Article 267 TFEU and the borderline between Union law and national law, the ECJ's competence, as noted above, being in principle limited to the former. The following observations will focus on some institutional and procedural challenges concerning the division of labour between the ECJ and the national court when dealing with requests for preliminary rulings.

A few years ago, when the ECJ undertook to recast its Rules of Procedure, it was decided to include a provision laying down some basic requirements on the content of a request for a preliminary ruling. Article 94 of the new Rules of Procedure, adopted and entered into force in 2012,37 contains requirements relating to the subject-matter of the dispute and the findings of fact as determined by the referring court, the national law applicable in the case and the reasons which prompted the referring court to inquire about the interpretation or validity of certain provisions of Union law. The ECJ has recently confirmed that the national court should be

34 Da Costa, Joined Cases 28-30/62, Judgment of 27 March 1963 [1963] EU:C:1963:6 (English special edition, p 31). See also e.g. Shipping and Forwarding Enterprise Safe BV, Case 320/88, Judgment of 8 February 1990, [1190] EU:C:1990:61, paras. 10-13; the case law cited in M. Broberg \& N. Fenger, Preliminary References to the European Court of Justice, $2^{\text {nd }}$ ed. (2014), 156-157. For a more recent judgment referring to the distinction between application and interpretation, see Airport Shuttle Express and Others, Joined Cases 162/12 and 163/12, Judgment of 13 February 2014, [2014] EU:C:2014:74, para. 31.

35 CILFIT, Case 283/81, Opinion of AG Capotorti of 13 July 1982, [1982] EU:C:1982:335. See also Wiener, Case 338/95, Opinion of AG Jacobs of 10 July 1997, [1997] EU:C:1997:552; Broberg \& Fenger, supra note 34, 156-157.

36 See e.g. C. Naomé, Le renvoi préjudiciel en droit européen, $2^{\text {nd }}$ ed. (2010); Broberg \& Fenger, supra note 34.

37 Rules of Procedure of the Court of Justice, supra note 25. According to Article 253(6) TFEU, the Rules of Procedure are to be established by the Court of Justice but they require the approval of the Council (which consists of representatives of the national governments). 
aware of the requirements concerning the content of a request for a preliminary ruling, as set out in Article 94, "which it is bound to observe scrupulously".38 The following discussion will be partly based on this provision as well as the Recommendations to national courts and tribunals issued by the ECJ, most recently at the end of 2016. ${ }^{39}$

It should be underlined that the decision whether to submit a case to the ECJ is in the hands of the national court. The Recommendations that the ECJ has addressed to national courts state that " $[t]$ he jurisdiction of the Court to give a preliminary ruling on the interpretation or validity of EU law is exercised exclusively on the initiative of the national courts and tribunals". And this is "whether or not the parties to the main proceedings have expressed the wish that a question be referred to the Court". It is thus for the national court to determine "both the need for a request for a preliminary ruling in order to enable it to give a judgment and the relevance of the questions which it submits to the Court". 40

An obvious limitation of the ECJ's jurisdiction consists of the fact that it is limited to interpreting, and in the case of secondary law, assessing the validity of Union law, not national law. The need to differentiate between Union law and national law has become particularly acute with respect to the applicability of the Charter of Fundamental Rights of the European Union, Article 51 of which prescribes that its provisions are addressed to the Member States "only when they are implementing Union law".41 Whilst the ECJ has declined to give a restrictive interpretation of what constitutes "implementing [Union law]", 42 there is already by now a string of judgments and reasoned orders where the Court denies competence to apply the Charter as the situation was not considered to fall within the scope of application of Union law (that is, to constitute implementation of this law in the sense of Article 51(1) of the Charter). ${ }^{43}$

The requirement that the case concerns the interpretation of Union law, not national law, has not prevented the Court from heeding to requests for

38 Ognyanov, supra note 29, para. 19.

39 Recommendations, supra note 26.

40 Ibid., para. 3.

41 See e.g. A. Rosas, The Applicability of the EU Charter of Fundamental Rights at National Level, 13 European Yearbook on Human Rights (2013), 97.

42 See in particular Åkerberg Fransson, Case 617/10, Judgment of 26 February 2013, [2013] EU:C:2013:280, paras. 16-31.

43 For examples, see Siragusa, Case 206/13, Judgment of 6 March 2014, [2014] EU:C:2014:126; Torralbo Marcos, Case 265/13, Judgment of 27 March 2014, [2014] EU:C:2014:187. 
the interpretation of rules of Union law even if the applicability of Union law in the national litigation in question has not followed from Union law itself. ${ }^{44}$ This has occurred mainly in the following two types of situation: 1) the request for a preliminary ruling has mentioned the fact that national law refers to Union law in a way which calls for an interpretation of the latter in order to arrive at the correct interpretation of the former; ${ }^{45} 2$ ) a national constitutional principle instructs national courts to extend the protection offered by Union law to purely internal situations not covered by Union law so as to avoid that people in the former situations be treated less favourably than those who can invoke Union law directly. ${ }^{46}$

The Court has not been very strict in this regard, however, and sometimes the mere fact that a reply might be useful to the national court, in the event that its national law required that its own nationals not be given less favourable treatment than nationals of other Member States, has satisfied the Court that it should give a ruling. ${ }^{47}$ Moreover, there are some cases where the Court seems to have answered the questions put by the national judge simply by assuming that the interpretation of Union law given would be relevant in a cross-border situation, despite the fact that there was nothing in the national litigation that suggested such cross-border elements. ${ }^{48}$ As noted by an Advocate General of the Court, in preliminary ruling cases involving situations of national rather than Union law, "the Court has adopted a variety of approaches" ${ }^{49}$ In a recent judgment, the Court has clarified the demarcation between Union law and national law and hence

44 See generally e.g. V. Kronenberger, Actualité du renvoi préjudiciel, de la procédure préjudicielle d'urgence et de la procédure accélérée - Quo vadis?, in S. Mathieu (ed.), Contentieux de l'Union européenne : Questions choisies (2014), 397, 401-412.

45 See e.g. Dzodzi, Joined Cases 297/88 and 197/89, Judgment of 18 October 1990, [1990] EU:C:1990:360; Leur-Bloem, Case 28/95, Judgment of 17 July 1997, [1997] EU:C:1997:369. See also Naomé, supra note 36, 124-126.

46 See, e.g. Guimont, Case 448/98, Judgment of 5 December 2000, [2000] EU:C:2000:663; Centro Europa, Case 380/05, Judgment of 31 January 2008, [2008] EU:C:2008:59. See, also; Naomé, supra note 36, 121.

47 See e.g. Anomar and Others, Case 6/01, Judgment of 11 September 2003, [2003] EU:C:2003:446, para. 41.

48 See e.g. Blanco Pérez and Chao Gómez, Joined Cases 570/07 and 572/07, Judgment of 1 June 2010, [2010] EU:C:2010:300, para. 40 and the case law cited; Venturini and Others, Joined Cases $159 / 12$ to $161 / 212$, Judgment of 5 December 2013, [2013] EU:C:2013:791, paras. 25-26, see also paras. 27-28.

49 Sbarigia, Case 393/08, Opinion of AG Jääsinen of 11 March 2010, [2010] EU:C:2010:388, para. 29. See also Venturini and Others, Joined Cases C-159/12 to C-161/12, Opinion of AG Wahl of 5 September 2013, [2013] 
between its jurisdiction and that of national courts in a way which seems to suggest that the Court will in the future insist on the existence of sufficient connecting factors with Union law in order to be able to give a ruling. ${ }^{50}$

The above situations are normally treated by the Court as questions of competence. It may also declare a request non-admissible if it is not satisfied that a ruling is necessary or possible. Whilst the Court, in a spirit of cooperation, regards itself in principle obliged to answer questions referred under Article 267 TFEU, it considers itself competent to verify the necessity of the request. ${ }^{51}$ In this regard, the Court verifies that the request relates to an actual case (an action) pending before the national court, including that the case is not fictitious. ${ }^{52}$ It may also declare a request as non-admissible where it sees no usefulness or relevance of the questions referred before the national court, where the problem raised is of a hypothetical nature, ${ }^{53}$ or if it considers the request as so lacking in relevant information that it becomes more or less impossible to understand what is being requested. ${ }^{54}$

ECLI:EU:C:2013:529, paras 16-71. See further Kronenberger, supra note 44, 407-408, 409-410,411-412.

50 In Ullens de Schooten, Case 268/15, Judgment of 15 November 2016, [2016] EU:C:2016:874, the Court held that EU law cannot give rise to non-contractual liability of a Member State when the circumstances of the dispute in the national proceedings, in the absence of explications to the contrary provided by the national referring court in application of Article 94 of the Rules of Procedure of the ECJ, do not display any connecting factor with provisions of Union law.

51 See e.g. UGT-Rioja and Others, Case 428/06, Judgment of 11 September 2008, [2008] EU:C:2008:488, para. 40; see also Naomé, supra note 36, 107.

52 See in particular Foglia/Novello, Case 104/79, Judgment of 11 March 1980, [1980] EU:C:1980:73.

53 An example of a refusal to reply to a hypothetical question is offered by Meilicke, Case 83/91, Judgment of 16 July 1992, [1992] EU:C:1992:332. For a more recent example see, Societá cooperative Madonna dei miracoli, Case 82/13, Order of the Court of 7 October 2013, [2013] EU:C:2013:655, paras. 12, 14; see generally Naomé, supra note $36,115-122$, where it is pointed out (para. 118) that in the case law of the Court, there is some overlap between non relevant and hypothetical questions.

54 See e.g. Viacom Outdoor, Case 190/02, Order of the Court of 8 October 2002, [2002] EU:C:2002:569, where the Court stated, inter alia, that "[i]n the absence of sufficient particulars, it is not possible to discern the specific problem of interpretation which might be raised in relation to each of the provisions of Community law in respect of which the national court seeks an interpretation" (para. 22) and the follow-up case Viacom Outdoor, Case 134/03, Judgment of 17 February 2005, [2005] EU:C:2005:94, para. 31, where it is observed that the order for reference 
Such an outcome does not necessarily apply to all the questions referred by the national court.

This is not the place to enter into a discussion as to the precise limits of the Court's jurisdiction in these and similar situations. What is of primary interest here is to consider what implications such problems of competence and jurisdiction may have for the requirements imposed by Article 267 TFEU and Article 94 of the Rules of Procedure as to the respective tasks of the national court and the ECJ and the requirements on the content of the request for a preliminary ruling. It is to this question that we shall now turn.

\section{The Request for a Preliminary Ruling}

Before the adoption of the Rules of Procedure of the ECJ of 2012, the only legally binding provision setting out conditions for a request for a preliminary ruling was Article 267 TFEU. Apart from the condition that, in the view of the national court, a decision on the interpretation and, as the case may be, validity of acts of Union law "is necessary to enable it to give judgment"; there were no explicit requirements on the content of the request itself. True, some guidelines in this regard were provided in an Information Note on references from national courts for a preliminary ruling (replaced by Recommendations to the same effect of 2012 and 2016, respectively ${ }^{55}$ ), but as the title suggests, this Information Note (in the same vein as the Recommendations succeeding it) was not legally binding. ${ }^{56}$

Article 94, entitled "Content of the request for a preliminary ruling", of the Rules of Procedure is designed to remedy this situation. Article 94 provides that in addition to the text of the actual questions referred to the Court for a ruling, the request shall contain some information relating to the factual situation with which the national judge is faced, the national law applicable in the main proceedings (including, where appropriate, the relevant national case law) as well as the reasons which prompted the referring court to inquire about the interpretation or validity of Union law and the relationship between the relevant provisions of Union law and the national legislation applicable to the main proceedings.

"does not contain sufficient information" about certain relevant elements of fact and national law.

55 See Recommendations, supra note 26.

56 [2011] OJ C160/1; see also Broberg \& Fenger, supra note 34, 295-321, which contains a detailed discussion on the form and content of a reference. 
It is obvious that this information is of considerable importance for the Court in considering whether it is competent to give a ruling and whether the request should be declared admissible. Subparagraph c) of Article 94, concerning the need to explain the reasons which prompted the national court to refer the case to the ECJ and the relationship between the relevant provisions of Union law and of national law, is particularly important with respect to questions relating to the jurisdiction of the Court (above all, whether the case raises a point of Union law or not ${ }^{57}$ ). The ECJ has recently held that the requirements set out in Article 94 must be observed regardless of national rules which, to the contrary, oblige the national court to disqualify itself from the case on the ground that it set out, in its request for a preliminary ruling, the factual and legal context of the case..$^{58}$

After having repeated the above requirements set out in Article 94 of the Rules of Procedure, the Recommendations issued by the ECJ state that the national court must provide references for the national provisions applicable to the facts of the dispute and "should accurately identify the provisions of EU law" whose interpretation is sought of whose validity is challenged. The request should include, if need be, a brief summary of the relevant arguments of the parties to the main proceedings. ${ }^{59}$ As noted above, an example of a situation where it is particularly important that the relevant Union law be identified as accurately as possible is a situation which raises doubts about the applicability of the Charter of Fundamental Rights, in other words whether a rule of Union law other than a provision of the Charter can be identified which, apart from concerns for its validity, should be either applied or interpreted in the case in question. ${ }^{60}$

For the question of admissibility, for instance whether there is a real case or whether the litigation is fictitious, an explanation of the facts of the case and of relevant national law may be equally relevant. Even if the Court is not competent to establish the facts, or to rule on the correct interpretation of national law, accurate and precise information on these questions will often be essential in order for the Court to understand the legal issues involved and the possible implications of a ruling to be given by it. It is true that the preliminary ruling procedure does not, in itself, constitute a direct action (such as action for annulment) brought by one party against

57 This includes the question as to whether there is a provision of Union law other than the Charter of Fundamental Rights which is relevant (given that the Charter can never be applied on a stand-alone basis, see supra notes at 41-43).

58 Ognyanov, supra note 29.

59 Recommendations, supra note 26, para. 16.

60 See Rosas 2012, supra note 18, 105-110, 111-112. 
another but mandates the ECJ to give a binding ruling on questions of interpretation (or validity) of Union law formulated by national judges. It is, nevertheless, also true that the proceedings before the ECJ constitute an integral part of a broader endeavour to settle a real dispute initially brought before the national court, and that both the initial and the final say belongs to the latter. As the ECJ is not called upon to give abstract rulings but to contribute to the settlement of a concrete dispute, the facts of the case and the state of national law (particularly the interaction between Union and national law) must be taken into account also by the ECJ.

The Recommendations to national courts and tribunals in relation to the initiation of preliminary ruling proceeding $s^{61}$ thus underline the nature of the decision of the national court as a document which will serve as the basis of the proceedings before the Court and that it must contain such information as will enable the Court to give a reply which is of assistance to the referring court or tribunal. The request must on the one hand be succinct but on the other sufficiently complete and should be drafted "simply, clearly and precisely [...] avoiding superfluous detail".62

The Recommendations also invite the referring court to "briefly state its view" on the answer to be given to the questions referred, as that information "may be useful to the Court, particularly where it is called upon to give a preliminary ruling in an expedited or urgent procedure". ${ }^{3}$ Thus, not only is the national court the master of the decision whether to refer or not, and of the formulation of the questions to be put to the ECJ, but it is also invited to suggest, if it sees fit, the answers to be given by the ECJ to the questions of interpretation or validity of Union law. It is the experience of the present author that such suggestions, while not being binding for the ECJ, may aid the Court to understand the legal issues involved and the reasons for the national court to turn to the ECJ for assistance.

The ECJ, in its recent case law, has started to refer to Article 94 of the Rules of Procedure notably in determining whether the request for a preliminary ruling should be declared inadmissible. This has been done by recalling first the case law of the Court concerning the admissibility of such requests and then adding that the requirements following from this case

61 Recommendations, supra note 26.

62 Ibid., para. 14. On expedited and urgent procedures before the ECJ, see A. Rosas, Justice in Haste, Justice Denied? The European Court of Justice and the Area of Freedom, Security and Justice, 11 Cambridge Yearbook of European Legal Studies (2009-2009), 1.

63 Ibid., para. 17. 
law are now expressed in Article 94 of the Rules of Procedure, ${ }^{64}$ or by taking Article 94 as the point of departure for an examination of whether the content of the request is sufficient to enable the Court to give a ruling. ${ }^{65} \mathrm{In}$ other decisions, the Court has simply recalled its case law without referring explicitly to Article 94, which is partly explained by the fact that the order for reference had been made before the entry into force of the Rules of Procedure on 1 November 2012. ${ }^{66}$ The Court has also referred to Article 94 in determining whether the Court is competent to give a ruling on a question relating to the applicability of the Charter of Fundamental Rights under its Article $51 .{ }^{67}$

The current workload of the ECJ, and the increasing number of references for preliminary rulings referred to above in particular, seem to call for a somewhat stricter approach to the questions of competence and admissibility than was necessary in the old days of considerably fewer such requests. True, Article 101 of the Rules of Procedure provides the Court with the possibility to request clarifications from the referring court within a time limit prescribed by the Court. This possibility is rarely used. This is partly because experience shows that the deficiencies of orders for reference are not always fully rectified through this procedure, partly because the procedure is time-consuming and may also cause procedural problems for the national judge. It may, in fact, be difficult for the national court to treat the request expeditiously while respecting fully the procedural rights of the parties to the main proceedings, in view of the applicable national procedural rules.

64 See e.g. Mlamali, Case 257/13, Order of the Court of 14 November 2013, [2013] EU:C:2013:763, para. 22; Grimal, Case 550/13, Order of the Court of 19 March 2014, [2014] EU:C:2014:177, para. 16 (these Orders of the Court are not available in English); see also Adiamix, Case 368/12, Order of the Court of 18 April 2013, [2013] EU:C:2013:257, para. 22, where the Court referred to the Information Note on references from national courts for a preliminary ruling (which preceded the Recommendations issued in 2012 and 2016, respectively), see supra note 26, and for two more recent judgments, Ognyanov, supra note 29, paras. 19, 21, 22; Ullens de Schooten, supra note 50, para. 55.

65 Debiasi, Case 560/11, Order of the Court of 13 December 2012, [2012] EU:C:2012:802, para. 24, not available in English.

66 See e.g. SC Mora IPR SRL, Case 79/12, Judgment of 21 February 2013, [2013] EU:C:2013:98; Sky Italia, Case 234/12, Judgement of 18 July 2013, [2013] EU:C:2013:496; Zentralbetriebsrat der gemeinnützigen Salzburger Landeskliniken Betriebs GmbH v. Land Salzburg, Case 514/12, Judgment of 5 December 2013, [2013] EU:C:2013:799.

67 Siragusa, supra note 43, para. 19. 
A much more frequently used mechanism is for the ECJ to resort to Articles 61 and 62 of its Rules of Procedure ${ }^{68}$ ("Measures of organisation prescribed by the Court"). According to Article 61, the Court may invite the parties or other interested persons to answer certain questions in writing, or at the hearing. Article 62 again provides that the Judge-Rapporteur or the Advocate General may invite the parties and interested persons "to submit within a specified time-limit all such information relating to the facts, and all such documents or other particulars, as they may consider relevant".

Probably the most often used measure of organisation is to invite the parties and/or interested persons to answer questions at the hearing. The Rules of Procedure (Article 76) enable the Court to refrain, under certain conditions, from organising a hearing even if a hearing has been specifically requested but this has not led the Court to avoid organising such hearings to any significant degree. Instead, the Court has taken an active role in the planning and organisation of the hearings and this has also led to a more frequent use of Articles 61 and 62 of the Rules of Procedure. ${ }^{69}$

These measures quite often strive to elucidate factual questions and/or issues of national law, within the framework of the questions concerning Union law put by the national court, so as to clarify issues which, in the view of the Court, have not been sufficiently explained in the order for reference. That said, it should be underlined that if there is a conflict between the interpretations of national law as presented by the national court and that presented, for instance, by the national government concerned, the Court will normally follow the interpretation put forward by the former. ${ }^{70}$

Article 94 of the Rules of Procedure offers an opportunity and a more explicit legal basis for insisting on some minimum requirements for the orders for reference as formulated by national courts. It is important to encourage the national courts to provide an accurate and clear account of the legal and factual aspects of the case and thus help both the interested parties, including the national governments and the Commission, and the

68 Rules of Procedure, supra note 25.

69 A. Rosas, Oral Hearings before the European Court of Justice, 21 Maastricht Journal of European and Comparative Law (2014), 596, 607-609; see also the Practice Directions to Parties Concerning Cases Brought before the Court, adopted in accordance with Article 208 of the Rules of Procedure, [2014] O.J. L 31/1, paras. 45, 50-52.

70 See e.g. Orfanopoulos and Oliveri, Joined Cases 482/01 and 493/01, Judgment of 29 April 2004, [2004] EU:C:2004:262, para. 43, and for more examples of case law Broberg \& Fenger, supra note 34, 372-374, including some cases where the Court seems exceptionally to have departed from the interpretation put forward by the national judge. 
ECJ itself, to have a solid basis for an examination of the questions referred. This, again, could enhance the quality of this examination and at the same time even help to shorten the duration of the proceedings before the ECJ. Moreover, the better the ECJ has understood the issues at stake and been able to translate this understanding into a clear reasoning and result, the easier it will be for the national judge, called upon to deliver the final verdict, to absorb the ECJ ruling relating to the interpretation or validity of Union law for the purposes of adjudicating the dispute before it. The final judgment rendered by the national judge may be said to constitute an amalgamation of Union law as interpreted by the ECJ, the facts of the case and, as the case may be, applicable national law.

\section{A Single Judicial System}

The above observations have focused on the division of labour between the ECJ and the national courts and the interaction between the two in the context of the preliminary ruling procedure. This interaction is important to guarantee that the preliminary ruling procedure fulfils its purpose and that the overall handling of the case (by the national court and by the ECJ) is susceptible to lead to a good result which is also satisfactory from a procedural point of view. As the ECJ observed in Opinion 1/09, the national courts and the ECJ "fulfil a duty entrusted to them both" of ensuring that in the interpretation and application of the Treaties, the law is observed and the national courts are "closely involved in the correct application and uniform interpretation of European Union law and also in the protection of individual rights conferred by that legal order". ${ }^{11}$

The tasks which are incumbent upon the national courts have been gradually specified in the evolving case law of the ECJ relating to the institutional and procedural aspects of the preliminary ruling procedure. The Rules of Procedure of the Court, as supplemented by the Recommendations addressed to national courts issued by the Court, have further clarified the situation. ${ }^{72}$ Article 94 of the Rules of Court of 2012, contains requirements as to the content of a request for a preliminary ruling which is particularly instructive in this regard. The ECJ has recently underlined the binding nature of this provision and the obligation of national courts to observe the requirements laid down therein, if need be by setting aside na-

71 Opinion 1/09, supra note 20.

72 Rules of Procedure, supra note 25; Recommendations, supra note 26. 
tional rules incompatible with Article $94 .{ }^{73}$ The Court, in other words, treats its Rules of Procedure as a normative act binding also on the national courts. ${ }^{74}$ It should be noted that the Court's mandate to establish its Rules of Procedure is based directly on primary law, namely Article 253(6) TFEU, and that their adoption requires the approval of the EU Council. ${ }^{75}$

These developments seem to call for the following general observations: first, for an understanding of the preliminary ruling procedure before the ECJ, it is necessary to consider the institutional and procedural aspects which are specific for this procedure, and in particular those concerning the division of labour and the interaction between the ECJ and national courts which has been outlined above. These aspects are also crucial in guaranteeing that the procedure functions both smoothly and efficiently but also in full respect of the principle of effective judicial protection and relevant procedural guarantees.

Second, the respective roles played by the ECJ and national courts, the interaction between them, and the obligation of national courts to apply Union law directly, and including in situations which do not prompt the national court to request a preliminary ruling from the ECJ, give rise to an observation of a more constitutional character. We are not witnessing a dichotomous relationship between two separate judicial systems but two levels of one single judicial system.

As mentioned in Section II, the interaction between the ECJ and national courts is paralleled by an increasing intertwinement of Union law and national law. We seem to have reached the stage where, while one can still speak of two legal orders, at least when emphasizing their different historical origins, it has become appropriate to consider them as part of the same legal system. We are once again witnessing a cleavage between political and legal reality, the political discourse of today focusing on various perceived EU crises, problems of legitimacy and, for some, even the possible or likely dissolution of the Union, whilst the legal order appears to continue its

73 Ognyanov, supra note 29.

74 The Rules of Procedure also contain other provisions than Article 94 which apply to national courts, see, e.g. Article 102, according to which it shall be for the referring national court to decide as to the costs of the preliminary ruling proceedings.

75 The Rules of Procedure thus seem to be situated at the same hierarchical level as regulations and directives adopted by the Council and, as the case may be, the European Parliament. The practice rules for the implementation of the Rules of Procedure, provided for in Article 208 of the latter, may, in their turn, be likened to the implementing acts which the Commission, or as the case may be, the Council, may adopt by virtue of Article 291(2) TFEU. 
journey towards an increasingly constitutional order. It would go beyond the scope of this contribution to try to answer the question what will be the consequences of this cleavage in the years to come. Suffice it to note that it would seem that this cleavage has only to a limited extent had a spillover effect on the EU judicial system, and the preliminary ruling procedure in particular. ${ }^{76}$

76 But see the - albeit rare - instances referred to above, supra note 33 , when national courts have refused to follow judgments of the ECJ, or at least formulated reservations in this regard. 
